Article

\title{
Fostering Social Inclusion through Multilingual Habitus in Estonia: A Case Study of the Open School of Kalamaja and the Sakala Private School
}

\author{
Svetlana L'nyavskiy-Ekelund ${ }^{1, *}$ and Maarja Siiner ${ }^{2}$ \\ ${ }^{1}$ Centre for Language and Literature, Lund University, 22362 Lund, Sweden; E-Mail: svetlana.Inyavskiy@slav.lu.se \\ ${ }^{2}$ Center for Multilingualism in the Society across the Lifespan, University of Oslo, 0313 Oslo, Norway; \\ E-Mail: maarja.siiner@iln.uio.no \\ * Corresponding author
}

Submitted: 20 August 2017 | Accepted: 27 November 2017 | Published: 22 December 2017

\begin{abstract}
After the restoration of independence in 1991, Estonia continued with a parallel school system with separate public schools operating for Russian- and Estonian-speaking children. Seen as a developmental 'growing pains' of a transitional state, during the last 27 years the separate school system has contributed to infrastructural difficulties, educational injustice, and societal segregation. This article investigates the role of private schools in addressing this injustice from the analytical angle of new institutionalism, structuration and intergroup contact theories. How do these institutions challenge and aim at changing the state language regime or path dependency in the language of education? Two case studies are presented in this article: The Open School, established in 2017 for children with different home language backgrounds and targeting trilingual competences; The Sakala Private School, established in 2009, offering trilingual education with Russian as a medium of instruction. During this period of nation-state rebuilding and globalization, we investigate whether developing a multilingual habitus is a way to address the issue of social cohesion in the Estonian society in. So far, no other studies of private initiatives in Estonian language acquisition planning have been done.
\end{abstract}

\section{Keywords}

democratization; Estonia; integrated school; language acquisition planning; multilingual habitus; social inclusion

\section{Issue}

This article is part of the issue "Multilingualism and Social Inclusion", edited by László Marácz (University of Amsterdam, The Netherlands/Gumilyov Eurasian National University, Kazakhstan) and Silvia Adamo (University of Copenhagen, Denmark).

(C) 2017 by the authors; licensee Cogitatio (Lisbon, Portugal). This article is licensed under a Creative Commons Attribution 4.0 International License (CC BY).

\section{Introduction}

In our article, we claim that the link between Language Acquisition Planning (LAP) and democratization is a twoway process; furthermore, we argue that plurilingual education, based on the current view on plurilingualism as a cultural and societal enrichment, requires a certain level of democratization in a society. We investigate how the private schools Kalamaja and Sakala contribute to the changes of the state language regime and path dependency in the language of education and examine the role of those private institutions in addressing social injustices in Estonia from the analytical angle of new in- stitutionalism (Peters, 2011; Sonntag \& Cardinal, 2015), the structuration (Giddens, 1984; Siiner, 2012), and intergroup contact theories (Pettigrew \& Tropp, 2006). Moreover, we contribute to the increasing body of research that studies the role of language policy agents other than the state, in Estonia in facilitating change (Siiner, Koreinik, \& Brown, 2017). To our knowledge, this is the first study addressing the role of private schools in paving the way to change in LAP in Estonia; finally, we argue that initiatives like these are necessary for finding an alternative solution to the problems of separate education and segregation in the Estonian society. To exemplify this, we present case studies of two private schools from Tallinn, the capi- 
tal of Estonia, that provide multilingual education and are open to both Estonian and Russian speaking children. We conceptualize these initiatives as private language policy agents aiming at changing the separate school system that has been a serious upset to social cohesion. First, we present a short overview of the parallel school system genesis; second, we outline our theoretical and methodological framework for the study; lastly, we apply it to our analysis of the two private school initiatives. We finish this article with a discussion of the social action and process our cases indicate, and the changes they might bring to language education policy in the future.

Robert Cooper extended the notion of language planning and policy (LPP) to LAP alongside with status and corpus planning, referring to the "organized efforts to promote the learning of a language" (Cooper, 1989, p. 157). In contrast to status and corpus planning research, which was primarily concerned with state initiatives, LAP was a complex task to solve via legislation and by institutional means (Cooper, 1989, p. 185). Through LAP research focusing on language users and their communicative repertoires, acquisition needed for access to various opportunities in society, an understanding emerged that LPP is not only about managing linguistic diversity but about managing social inequality in a society (Hornberger, 2006, p. 28). LAP research revealed how social inequality is often caused by state language policies ( $\mathrm{Ri}$ cento \& Hornberger, 1996), and how decentralization and democratization, especially the agency taken by the other policy stakeholders besides governmental educational institutions, can reduce inequality (Canagarajah, 2005). With increasing focus on the agency in a variety of categories, such as families (King, 2001), educational institutions became the important sites for LAP research, as they reveal mechanisms of ideological reproduction and preservation of state traditions.

The present article is about LAP in Estonia, where a parallel Russian and Estonian school system was inherited and kept functioning as a part of its Soviet legacy. Because of the large share of people who identified themselves as Russians ( $1 / 3$ of the population in 1991), continuous fear of Russian aggression (Galeotti, 2017) and lack of economic and pedagogical resources (considering that many teachers in Russian schools were monolingual (Kiilo \& Kutsar, 2013, p. 479), the inclusion of Russian children into Estonian schools was not carried out as part of the general normalization processes in the transitional state (Smith, 2003). Instead, amendments to the Law on Basic and Upper Secondary Schools were made to change the situation within the existing institutions, and a gradual transition to the Estonian language (at least $60 \%$ of the curriculum) was planned (Heidmets et al., 2011). The focus on language (of instruction) concealed the fact that institutions kept alive what Brown (2017) calls a "policy drag", the production and reproduction of attitudes and ideologies from the previous state. Many teachers of today have acquired the foundations of their practices and ideologies in the past; therefore, those out- dated language policies last beyond the formal life of the policies (Kiilo \& Kutsar, 2012). During the Soviet occupation, schools with the Russian language of instruction followed the curriculum of Russian Socialist Federative Republic (RSFR), while Estonian schools adhered to the local national curricula (Masso \& Soll, 2014, p. 519). Even if both schools had to follow a common curriculum after 1991, the Russian schools in many cases continued to see the schools in RSFR as a model and kept using Soviet time methods and textbooks (Lindeman, 2013, p. 51).

The separate school system also contributed to the development of children's monolingual habitus based on an assumption that a school class should be culturally and linguistically homogenous, and language education is about teaching children the standardized state language norm (Gogolin, 2008). The linguistic diversity experienced by children in their surroundings was not valued nor considered in the classroom interaction; moreover, it was often conceptualized as a disturbing factor (Siiner, 2012). Current research provides evidence of harmful impact and deepening division stemming from separate or segregated education systems that could be alleviated by inclusive multilingual schooling (Kiilo \& Kutsar, 2013, p. 475). In the meanwhile, the EU experienced a gradual shift from linguistic diversity recognition towards a plurilingual language education model (The Guide for the Development of Language Education Policies in Europe, 2017). With many new member state languages, the European Union is becoming increasingly multilingual; moreover, inclusion and communicative abilities are becoming essential for participation in democratic and social processes. Tolerance and acceptance of multilingualism are also framed as important for developing democratic citizenship (Byram, 2008). Those aspects are often missed in the Estonian LAP discussions. Most importantly, researchers failed to create a clear link between the absence of a unitary public school system and a common public platform for discussing the central issues, such as the problems of social inclusion, and of minimizing social inequalities between Estonians and Russian-speakers.

\section{Parallel School System: The Current Status}

After the independence, a number of external and internal factors, such as security concerns vis-à-vis Russia, lingering presence of Russian military on Estonian territory, the hardship and discrimination experienced by Estonians during the period of Soviet occupation, a much bigger share of Russian-speakers in Estonia and Latvia, as compared to Lithuania, made the countries perceive it as a serious threat to security and survival of their languages (Hogan-Brun, Ozolins, Ramoniene, \& Rannut, 2008; Schneider, 2015; Wlodarska-Frykowska, 2016). That is why, using the argument of 'state restoration' and other legal instruments, Latvia and Estonia established more restrictive citizenship, language policies and did not extend the status of historical national mi- 
nority to the diverse population of Russians, considering that at the time of independence the number of people speaking Russian constituted $71.88 \%$ of the Estonian population (Ehala, 2017; Kuutma, Seljamaa, \& Västrik, 2012; Ryazanova-Clarke, 2014). Lithuania could "afford" more liberal citizenship and language policies resulting in a greater success with linguistic integration. In Estonia, the restrictive policies did not bring about the desired result-the creation of a civil society and common information space in one language. The two language communities still live in cultural and linguistic segregation. After the post-Soviet language status reversal, the social inequality increased between the titular group and the Russian speakers, who were used to a privileged position but found themselves now in the low-income group. To a large extent, the Russian speakers also remained to a large extent in the information space of the Russian media, where different views on Estonia's present and past political developments circulated, the main controversy being the illegitimate Soviet occupation vs legitimate annexation of the Republic of Estonia by Soviet Union (Estonian Institute of Human Rights, 2015). The issue at stake was also the legitimacy of those Russian-speakers who moved to Estonia during the occupation, whose life in separate information space further increased the distrust between the two language groups (Siiner \& L'nyavskiy-Ekelund, 2017; Vihalemm \& HoganBrun, 2013).

The transition reforms outlined above failed largely due to the fact that the language of instruction in the lower secondary schools run by municipalities remained Russian only, and children who graduated from the lower secondary schools had insufficient Estonian language competence (minimum required level B1) (Lindemann \& Kogan, 2013). Russian schools lacked qualified teachers who could teach their subjects in Estonian and would move to the mostly Russian cities in the northeastern corner of Estonia. For a while, the issue of Russian schools was perceived by Estonian politicians as a developmental "growth pain" that Estonia would eventually pass (Põder et al, 2017). Although the number of Russian schools has been diminishing, the "policy drag" and social inequality it caused may last long into the future (Vihalemm \& Siiner, 2013). Focus on the language of instruction and linguistic integration has concealed the fact that Russian schools are part of a bigger (infra-) structural deficiencythe ethno-demographic residential and social segregation. Scarcity of regional development in the areas with a large share of Russian speakers, where the majority of Russian medium schools are located, is one important impact factor, and so is the distrust between the two language groups, the central government and the Russian speakers, who felt they were left behind (Kello, Masso, \& Jakobson, 2011; Siiner, 2014). In Tallinn, the tactics of gaining trust among the Russian-speaking population by fueling the distrust between the Russian-speaking population and the central government used by the ruling Center party have guaranteed them the majority of seats in the Tallinn city council. The discussions about the fate of Russian-medium schools have largely been hampered because of the distrust between the Russianspeaking minority, the Tallinn city council, and the central government.

The ethno-linguistic and residential division of Estonians and Russian speakers had emerged already in Soviet years when labor immigrants settled in newly built housing areas on the outskirts of the largest cities. These residential areas with a high density of Russian speakers and their schools have been connected by some researchers with a downward mobility (Leppik \& Vihalemm, 2015, p. 488). The census data from 2011 show, that while the residential areas where Russian speakers reside have remained mainly low-income, some areas, where Russianspeakers originally lived and that used to be low-status areas due to poor living conditions like Kalamaja, Pelgulinn, and Telliskivi, are now experiencing gentrification and have turned into high-status areas (Põder et al., 2017) increasingly preferred by new Finnish and English speaking migrants (2011 Census data). While Estonians previously escaped areas with Russian speakers, now multilingual neighborhoods like these are gaining popularity, and a new type of transnational and multilingual identity is emerging in Estonia, also shaping the views on language education policies. The most prominent advocate for the early multilingual education is the present Estonian president Kersti Kaljulaid, ${ }^{1}$ who has resided in Luxembourg for 12 years. These contextual and discursive changes have been decisive for the private school initiatives that we will outline below. But first, we explain the conceptual basis for our study.

\section{Theoretical Basis}

Our analysis is partially based on the new institutionalism framework that studies formal institutions as well as individual actors (Peters, 2011), as it provides the insights into resources and support for the continuation of societal rituals and traditions that prevent unwanted change (Giddens, 1984). Institutions that are based on rituals and traditions can continue to work even if they are no longer functional. In the field of education, institutionalization is especially needed to guarantee stability and predictability. In his structuration theory, Giddens illuminates the constitutive, although amenable to change, character of social structures, a set of rules, which individual or collective social agents draw on to enact or change social practices. The social actors' agency is based on its access to necessary authoritative and allocative resources (Giddens, 1984). Authoritative resources available to the agent determine the agent's position in the social hierarchy and decide whether the agency is possible at a given time in a given context. The alloca-

\footnotetext{
${ }^{1}$ The speech given on 2 February 2017, where the Estonian president Kersti Kaljulaid addressed multilingualism and intercultural competencies as important 21st century skills can be found here: https://president.ee/et/ametitegevus/koned/13056-2017-02-15-08-00-59/index.html
} 
tive resources determine whether the act is doable-i.e., whether the available discursive and material resources are sufficient (Siiner, 2012).

In this article, we study private educational institutions. The public educational institutions often follow a state tradition and are path dependent-they exist until the state or municipality dissolves them (Sonntag \& Cardinal, 2015). As a rule, private educational institutions are more flexible and created when a group of founders has identified a need for a different educational approach than the one present in the public educational system. Private schools are subject to the market forces and depend on a market in order to attract pupils. Parents, as consumers, also have a greater influence in private schools than in public schools; thus, it is more likely that private schools can be game-changers; and parents, whose needs are in turn directed by discursive and sociopolitical changes in the society, would often dictate their direction. It is not always enough to have authority to take agency (for the change)-it is also important to have the necessary authoritative and discursive resources, i.e., that one's position and authority is accepted by the larger society and that one's voice will be heard.

The available discursive resources depend on the agents' position within society but also on the discursive changes in language ideological debates (Blommaert, 1999). In the recent years, the instrumental value of Russian and English has increased-these two languages are often used to supplement Estonian in the public space, as so many signs, public web pages, events, etc., became trilingual (Berezkina, 2015). Learning Russian is again gaining popularity among young people for practical reasons, and Estonian parents want their children to learn it from the early age. It is within this changed societal context that we will look at the two private schools founded in Tallinn that aim to contribute to multilingual education. Based on structuration theory (Giddens, 1984) and the new institutionalism (Sonntag \& Cardinal, 2015), we argue that a certain level of democratization has been taking place for such private initiatives to happen. Those initiatives are born from the tension between the gradual understanding that the existing institutions are not capable of guaranteeing societal and political change, the need to offset the segregating effects of the separate schooling, the need to balance the interests of different ethnic groups, and the need for a change to guarantee better social equality and cohesion.

A number of challenges for educational institutions in transitional societies pursuing institutional changes and the goals of social cohesion are identified by Loader and Hughes (2017, pp. 3-6): (1) to provide quality education in state language and mother-tongue while achieving societal integration aims; (2) to reconcile competing visions of multilingual integrated habitus with staff and parents; and (3) to promote the goals of social cohesion in the context of societal segregation and inequality. Our case selection interest and its analysis are also driven by the results of testing of the Intergroup Contact Theory (Allport, in Pettigrew \& Tropp, 2006), which confirms that an intergroup cooperation that is driven by common goals, supported by authorities and laws reduces intergroup prejudice. An investigation of societies with separate education systems due to prior conflicts, residential segregation, linguistic and religious preferences presented by Loader and Hughes (2017, p. 4) demonstrates that the preservation of such systems with monolingual schooling lacking intercultural contact usually results in the entrenchment of ignorance, prejudice, and segregation.

When it comes to finding educational solutions for balancing the interests of different ethnic groups, meeting the changes, and building a cohesive society, a study of two minority groups, Hungarians and Crimean Tatars, in Ukraine by Kulyk (2013) shows that exclusive instruction in Hungarian successfully reproduces the group's language and identity but curtails students' social mobility due to poor majority language skills. In contrast, the situation with Crimean Tatars demonstrates the danger to the group's language and identity reproduction due to lack of funds, no teachers trained in Crimean Tatar, and a diminished value of the language due to the number of external factors resulting in children being educated in other languages than Crimean Tatar (Kulyk, 2013).

At the same time, there are examples of separate education that can promote "beliefs and values consistent with social cohesion" (Loader \& Hughes, 2017, p. 4), such as a system of "shared education" initiated in Northern Ireland in 2007 and now supported by a large body of empirical evidence. The system promotes school's collaboration, facilitates sharing and pooling together financial resources, and creates consistent opportunities for schools to attend each other's classes for interacting and learning together while maintaining their unique cultural character. We will argue that the system of multilingual education gradually built by the administration of Sakala School has the characteristics of this strategy.

Working on the case of Kalamaja Open School, we understood that the system of integrated schooling (Loader \& Hughes, 2017, pp. 3-5), a private ground-up initiative also started by a group of concerned parents in Northern Ireland in 1981 and bilingual Jewish-Arab integrated schooling first founded in 1984 in Israel, is now offered in Estonia. The original initiative was aimed at bringing to the same classroom students from the groups usually educated apart; in the Northern Ireland, at first, it was supported by philanthropists and charities but later received full government funding and has grown to educate about $7 \%$ of students (Loader \& Hughes, 2017, p. 5). The studies of integrated schooling provide evidence of both positive and problematic effects produced by the system. Israeli and Northern Irish students' surveys found that "reduced social distance" promoted positive attitudes towards the other group as well as development of more adaptable, fluid and complex cultural identities; some of the critique of integrated schooling in both countries, a tendency to 
accentuate cultural differences in case of Israel and a tendency not to use the opportunities to challenge prejudice in case of Northern Ireland, seem to reflect the coping difficulties that educators have themselves, rather than the system's deficiencies (Loader \& Hughes, 2017, pp. 4-10).

\section{Methodology and Study Design}

Our research methods are inspired by the ethnographic approach and interpretive analysis to language and education policy which is particularly sensitive to research conducted in local contexts with emphasis on the role of local agents, language policy actors in (re)shaping and implementing institutional policies in practice (Canagarajah, 2006, pp. 153-154; Hornberger \& Johnson, 2007; McCarty, 2015, pp. 91-92). Studying the LAP agency, we have therefore analyzed the authoritative and allocative resources of two successful private schools, and what has made their agency possible. In our analysis, we have therefore studied the available information about the schools - their web pages and official documents. In addition, we conducted live semi-structures interviews of the school leaders, liris Oosalu (IO) and Jekaterina Gridneva (JG) from Sakala, a parent activist from Kalamaja, and social network-based questionnaires supplemented by semi-structured online interviews of 16 Sakala School students and graduates. The semi-structured interviews of the headmasters were initially conducted on Skype in June-July 2017; then, the transcripts were provided to the interviewees with an invitation to elaborate on the issues during the second interview. One hundred and sixty high-school students and recent graduates of Sakala gymnasium received the initial questions about their school choice, the importance of languages of instruction, their proficiency in Estonian and plans for the future; the answer rate $1 / 10$ provided us with 16 respondents who returned the initial questions and were willing to provide additional information with a guaranteed anonymity. Since the Kalamaja School opened first in September 2017, a similar study was not possible in their case. In our results' interpretation, relying mostly on qualitative and interpretive data analysis (SchwartzShea \& Janow, 2013), and the theories and empirical evidence mentioned above, we focused on the genesis of the institutions, resources available to them that made it possible, and how they address multilingualism in their school mission, bringing additional values to society. The students' interviews provided us with their personal insights into the separate educational system of Estonia they got to experience first-hand. The results of the analysis are outlined in the two case studies below.

\section{The Open School of Kalamaja}

Not only English but also Russian language competencies are increasingly valued by Estonians with middle and high income. It has been argued that due to gentrification in these mixed areas multilingualism and cultural di- versification are gaining value again as a factor contributing to a higher life quality (Leetmaa, 2017). Young Estonians moving to these areas are engaging in improving the life quality of the neighborhoods, forming local associations and actively participating in area planning. Therefore, it is not surprising that the first private school promoting trilingual language immersion in Estonian, Russian and English, with programming and digital competences as the fourth "language skill", The Open School of Kalamaja, was founded in one of those areas. The integrated classes (years 1 and 2) composed of the equal numbers of Estonians and Russian speakers and open to children with other home languages will start this fall of 2017. As a private school, the Open School is able to accept children from outside of the catchment area, but contrary to other private schools that carry out tests to cream off the best pupils in town, The Open School does not select students and accepts those first in line. The only criteria are that each class has an equal share of Estonian and Russian speaking students. Our parent activist reported a stronger interest in the program from Estonian-speaking families. The founders wanted to contribute to an open and strong society by rising openminded, engaging and grounded children.

We did not start with language focus; our goal was not to innovate language education policy. We wanted to found a school that could provide an excellent education to all children. We reached to this multilingual model through our search for research-based effective teaching practices/methods and community focus. Northern Tallinn is a multilingual area and you need languages here. The trilingual language immersion model and the community constitute a coherent whole. [IO]

The Open School is the first school in Estonia that will practice two-ways language immersion with one teacher using only one language (usually his or her native language) without translation. Teaching basic subjects and project work alternates between Estonian, English or Russian, keeping a predetermined weekly balance between languages. The teaching is based on national curriculum and follows a model where $60 \%$ of the subjects are taught in Estonian, 25\% in Russian and 15\% in English, depending on the grade. In the beginning, 55 percent of the classes will be taught in Estonian, $40 \%$ percent in Russian, and 5\% percent in English. Each semester kids engage in a five-week project that can be in all three languages.

Russian kids need to have a good command of their mother tongue, but they also need Estonian because it is the official language, and the majority of upper secondary schools and vocational schools are in Estonian, so with no command of the Estonian language, the child will have very limited choices. For an Estonian-speaking child, multilingual competences 
are important for doing well in the open society of tomorrow. [IO]

Many of the children who will start at school are already multilingual with multiple home languages, some have been living abroad. The positive value of multilingualism was implicit in the staff interviews. On the school's web-page a quadri-lingual competence is approached from the instrumental angle-in the future labor market we need languages and programming skills. Bringing the equal share of Estonian and Russian-speaking kids into one classroom is clearly seen as a necessary means of democratic education:

We cannot go on forever talking about the Russian and the Estonian school. It is about the time to talk about the SCHOOL. Some periods of history have different interpretations among the Estonian and Russian population. We do not have an answer how to handle that. For us, the cultural plurality is important. Kids in our school have different language and cultural backgrounds. It is important to deal with this aspect from early on. It's important to talk about politics and that people have different opinions. It is OK not to agree, but we need to have those issues on the table. $[\mathrm{IO}]$

The founders of the school were very clear and aware about the agency they take by founding the school. All founding members had a background either as entrepreneurs or had been active in an NGO with educational aims like the NGO KIVA, the anti-bullying program at schools or the NGO Noored Kooli that solves the challenge of the lack of qualified teachers at schools by bringing young specialists to teach at schools for a year. They wanted the school to be open for all and represent a cross-section of the society. The original idea was to open a new municipal basic school based on a trilingual model. No new municipal schools have been established in Tallinn since the restoration of independence. New schools have emerged through the merging of two schools or as private schools. But before they could become a municipal school they need to prove that the school model works: "It is typical to Estonia that new ideas are started by social entrepreneurs and eventually adopted by the state or municipality" [IO]. The founders had also experienced that the structural segregation has reached to the minds of people:

When we had our half-hour meetings with the parents so that they could get to know our school, we recognized that several Estonian families were worried whether Russian families would apply and that Russian families were worried about the same. See, we live side by side but how much contact do we have? The advantage of our school is that we bring these communities together and make them sit around the same table. We have already had our first family day in May when families got together. We did not divide them into different language groups but invited them all together. About four or five said that they do not speak Estonian, but some people volunteered to translate. [IO]

The founders approached the de facto multilingualism in the globalizing Estonian society as a mode of living, a rule that children should learn to live by and that the school should, therefore, prepare them for. The sort of multilingual habitus that this school aims to foster is not a precondition for social cohesion but something that an education for fostering open and socially aware children brings along.

\section{The Sakala Private School}

Russian private schools may have had a harder time in influencing the language education policy due to lack of their broader acceptance or legitimacy in the society. Russian language education is in general strongly politicized, and private school initiatives have previously gained media attention as attempts to avoid Estonian language instruction requirement (Siiner, 2014). Gaining trust from municipal politicians and the rest of society is easier for Estonian private schools. Below we will analyze how a Russian vs. an Estonian private school can advocate for a plurilingual educational model.

Sakala private school with the Russian language as the main medium of instruction was founded in 2009 in place of the old private school whose founder, for various reasons, could not continue running the establishment. The school location was determined by the building available at the time, in a prestigious location close to the Old Town in Tallinn. The school was founded to provide an alternative to public education and to "alleviate many of shortcomings in municipal schools by offering smaller classes, better student/teacher ratio, and a multilingual high-quality education" [JG]. The same advantages were reported by the students who emphasized the home-like atmosphere, small classes, and in-depth learning with a demanding program.

The school deliberately does not include "Russian" in its name, as the school's administration considers Estonian education system as unified, multilingual and democratic for supporting various educational choices with an option to use various languages to support the learning outcomes if needed, and due to the high politicization of the language question in Estonia, the school is trying to avoid. The school's mission statement (www.sakalaera.ee) outlines a set of society- and individual-oriented competencies:

Our goal is to promote maximal tolerance and education of the loyal citizens to their land. Unfortunately, the question of Russian as medium of instruction is very politicized and polarized: some politicians want to keep it at the level that would deprive the 
students of equal opportunities in Estonia but make them supportive of the ruling party's agenda for being allowed not to master the majority language, while the others want to eliminate it altogether....We want to raise self-standing, self-assertive individuals who would not care which language to use. And we are paying a special attention to the formation of those competencies while adhering to the high levels of academics. [JG]

The importance of instruction in Russian language lies in the strong interest of Russian-speaking community in giving students a chance to learn in their native language, and "it provided the opportunity for the students to focus on the academics and devote more time to language learning" [JG]; furthermore, the teachers saw that mastering difficult subjects in their native language ensured a good skills transferability when students had to switch to learning in other languages; moreover, "having three languages in their arsenal, excellent Russian (which is still in demand for practical reasons), free Estonian and English, and the opportunity to learn additional languages after school also provides the students with a competitive advantage, which would be simply stupid to eliminate" [JG]. About $40 \%$ of the students also confirmed that mastering difficult academic subjects in Russian was important, the other $30 \%$ said that they could do it in Estonian, but learning Russian was also to their advantage as it is spoken at home, among friends and gives more choices in life.

Originally, the school was not selecting the students with better academic aptitudes, but the school's popularity and a high-ranking allowed to apply certain criteria to the candidates in order to keep the demands of education program at the levels that attract families interested in academics. As a private institution, Sakala school has a lot of possibilities to decide how things should be done with the school's Guardian Council, parents, and the Student Council; moreover, for the superior authorities "the result is the most important, and we have good results, meaning that what we are doing works" [JG]. Early on, the school discovered that the language immersion system used for Estonian and Russian was not producing the desired results: the students could speak and read but were lacking written skills, even in Russian, so the school took an innovative approach to language education:

A few years ago the parents were concerned that our students spoke English better than Estonian. The standard program allocates two hours a week for Estonian, but the children forget everything in such short time of teaching, plus the topics of immersion program may not be interesting or relevant to them, so we decided to teach Estonian the same way we the teach the native language. Now we have 5 hours of Estonian per week, 5 hours of Russian and teach Estonian grammar, just like we do it for Russian. [JG]
Promoting social cohesion by ensuring the equal opportunities for its students, the school is particularly proud of its achievements in language teaching as the students receive the highest scores taking Estonian language exams, $90-92 \%$ average in B1, B2 and some in C1 levels. 15 out of 16 students indicated that it did not matter what language they had to use, as they were comfortable using their entire linguistic arsenal, 4 out of 5 school graduates reported successful entries to Estonian universities. "We will work on our Estonian bloc, but not for political reasons, for our students. We cannot live in the national state and be autonomous, this would be a dead end" $[J G]$.

One of the school's goals is to teach most of the non-academic subjects using at least two languages and mostly in Estonian: however, the problem is finding the specialists that could teach arts and crafts and use Estonian and Russian, if needed.

Establishing and maintaining intergroup contacts has been an important part of school's administrative effort. Sakala school has a partner, an Estonian language school of Saaremaa, with which they organize ski camps on the regular basis. The school is trying to participate in inter-school events as much as they can, but considers Saaremaa as a "strategic partner". After meetings like that, positive changes were noticed not only in the attitudes towards Estonian students but the whole country as well, with personal relations being formed and the fear of the "others" being gone away. The difficulties, yet again, lie with the school's older teacher's limited Estonian language skills, which excludes them from taking part, "Young Estonian teachers do not speak Russian, they speak English and that is a problem for our teachers as well. In general, the students have a lot easier ways of finding the common language" [JG]. Difficulties with regular intergroup contacts at the schools' level are compensated by the level of Estonian competence, as $95 \%$ of Sakala students reported that their level of Estonian allows them to participate in after-school activities mostly in Estonian without any limitations. All students that transferred to Sakala in search for better education and future prospects agreed that school's teaching methods made them reach a level of Estonian that allowed them to be engaged in all activities held outside the school, to make Estonian friends and successfully pass the exams.

The school's difficulties, according to the Headmaster, are associated with Russian schooling traditions:

It often feels like the school is trying to progress with the brakes on, while Estonian schools are freer and quicker to change and adapt to the new ways of Western teaching. Due to language limitations, our teachers are easily influenced by the information from the Russian sources and do not accept the changes easily. Also, Estonian schools have unarguable advantagethey do not have to maneuver between the languages. [JG]. 
As a headmaster, professional educator, and the entrepreneur, Jekaterina considers as her duty to follow, be open-minded and to keep the school open and responsive to the changes in the country, people's attitudes to languages and education, the fast-changing world of her students, and responsibilities that come with the mission vested in the system of education.

\section{Discussion}

In our article, for the first time, we analyzed how private, bottom-up initiatives in LAP are made possible by the democratization processes in Estonian society. The parallel school system in Estonia, separated along the language lines, is tied to the residential enclaves and differences in socio-economic status. The parallel school system also keeps alive the state tradition of the monolingual habitus. Dissatisfied parents are faced with an option to send their child to a school using a different language, move to a different school district or to commute solutions that do not solve the main problem (Siiner, 2012). A better solution could be the municipally supported private schools founded by parents that exist in Sweden, for example.

The two schools described are the examples of language political agency from below, but the case studies revealed important differences. The Estonian private school founders do not feel the urge to prove the existence of their school model by selecting the students and focusing on receiving the top results in national tests. They are confident with focusing on a holistic integrated education for children that goes in hand with community development and has proven to be successful by receiving a full municipal funding in the other countries with societies in transition. The Russian private school had to be more focused on the results as the way of proving the legitimacy of its existence, as well as on maneuvering the boundaries of language politics and downplaying the ethnic differences. They also seem less confident about having a voice to define the future of language education in Estonia, even though the school has been approaching the methods of a successfully working model of "shared education".

The study is limited by sampling only two schools in the capital of Estonia where two main linguistic groups are represented almost in equal proportions, thus providing the opportunity for the students to establish private contacts via extra-curricular activities, maintain and improve their language skills. The study would benefit from more extensive cross-sectional sampling from different private and municipal schools and regions of Estonia. The educational models analyzed here and the international experience of their implementation may provide salient solutions for the municipally supported "inclusive classroom" models in urban settings and "shared education" solutions in the areas densely populated by other linguistic groups.

\section{Conclusion}

Three separate processes have influenced the appearance of private multilingual schools we have analyzed in this article. First, the general movement towards private social entrepreneurship as a way to solve societal problems. Second, a response to the actual language situation and societal segregation in Estonia by the group of social entrepreneurs/educators by providing high-quality multilingual and mother-tongue minority education. The third one is a generally positive and instrumental attitude towards multilingual competences in the Estonian society.

None of the two schools have an explicit intention to change LAP, rather, they are interested in running an inclusive institution that educates engaged and openminded citizens able to manage the future society. This reflects a deep-rooted language ideology in the Estonian society that language political decisions belong to the realm of the state. What these schools have managed is to contribute to language ideological debate and challenge the monolingual habitus that the present LAP is based on. What concerns a shift in LAP, the jury is still out and will depend on the popularity of the schools.

\section{Acknowledgements}

We would like to thank the Headmasters of Sakala School and The Open School of Kalamaja, our anonymous Open School parent activist, and the upper secondary school of Sakala and its graduates for their time and help with this article.

\section{Conflict of Interests}

The authors declare no conflict of interest.

\section{References}

Berezkina, M. (2015). Russian in Estonia's public sector: "Playing on the borderline" between official policy and real-life needs. International Journal of Bilingual Education and Bilingualism, 20(4).

Blommaert, J. (1999). The debate is open. In J. Blommaert (Ed.), Language ideological debates (pp. 1-38). Berlin: Mouton de Gruyter.

Brown, K. D. (2017). Policy drag and resiliency: Teachers' response to voluntary language policy in southeastern Estonia. In M. Siiner, K. Koreinik, \& K. D. Brown (Eds.), Language policy beyond the State (pp. 183200). Cham: Springer.

Byram, M. (2008). From foreign language education to education for intercultural citizenship. Clevedon, UK: Multilingual Matters.

Canagarajah, S. (Ed.). (2005). Reclaiming the local in language policy and practice. Manwah, NJ: Lawrence Erlbaum.

Canagarajah, S. (2006). Ethnographic methods in lan- 
guage policy. In T. Ricento (Ed.), An introduction to language policy: Theory and method (pp. 153-169). Hoboken: Wiley.

Cooper, R. L. (1989). Language planning and social change. New York: Cambridge University Press.

Ehala, M. (2017). After status reversal. The use of titular languages and Russian in the Baltic countries. In $\mathrm{M}$. Flier \& A. Garziosipp (Eds.), The battle for Ukrainian (pp. 563-585). Cambridge: Harvard University Press.

Estonian Institute of Human Rights. (2015). Linguistic human rights and security. Retrieved from http://www. humanrightsestonia.ee/en/research-surveys/linguistic -human-rights-and-security

Galeotti, M. (2017). Controlling chaos: How Russian manages its political war in Europe. Retrieved from http://www.ecfr.eu/page/-/ECFR228_-_CONTROLLING CHAOS1.pdf

Giddens, A. (1984). The constitution of society: Outline of the structuration theory. Cambridge: Polity.

Gogolin, I. (2008). Der monolinguale Habitus der multilingualen Schule. Münster and New York: Waxmann Verlag.

Heidmets, M., Kangro, A., Ruus, V., Matulionis, A. V., Loogma, K., \& Zilinskaite, V. (2011). Education. Historical perspective: 20 years of reforms. Estonian Human Development Report 2010/2011, 96-114. Tallinn: Eesti Koostöö Kogu.

Hogan-Brun, G., Ozolins, U., Ramonienè, M., \& Rannut, M. (2008). Language politics and practices in the Baltic States. Current Issues in Language Planning, 8(4), 469-631.

Hornberger, N. H. (2006). 2006. Frameworks and models in language policy and planning. In T. Ricento (Ed.), An introduction to language policy: Theory and method (pp. 24-41). Malden, MA: Blackwell.

Hornberger, N. H., \& Johnson, D. C. (2007). Slicing the onion ethnographically: Layers and spaces in multilingual language education policy and practice. Tesol Quarterly, 41(3), 509-532.

Kello, K., Masso, A., \& Jakobson, V. (2011). Uurimisprojekti "Vene laps venekeelse üldhariduskooli eestikeelses õppes" koondaruanne ["Russian child in Estonian general education school" Final Project Report]. Tartu: Tartu Ülikooli Haridusuuringute ja Õppekavaarenduse Keskus.

Kiilo, T., \& Kutsar, D. (2012). When language becomes power: Russian-speaking teachers in the bilingual general education system in Estonia. British Journal of Sociology of Education, 33(2), 245-262.

Kiilo, T., \& Kutsar, D. (2013). Dilemmas related to the professional self-identity of Russian-speaking teachers in Estonia: Adapting and accommodating to changes in the language-in-education domain. Journal of Baltic Studies, 44(4), 475-502.

King, K. A. (2001). Language revitalization processes and prospects: Quichua in the Ecuadorian Andes. Clevedon, UK: Multilingual Matters.

Kulyk, V. (2013). Combining identity and integration:
Comparative analysis of schools for two minority groups in Ukraine. Compare: A Journal of Comparative and International Education, 43(5), 622-645.

Kuutma, K., Seljamaa, E. H., \& Västrik, E. H. (2012). Minority identities and the construction of rights in postSoviet settings. Folklore. Electronic Journal of Folklore, 51, 49-76.

Leetmaa, K. (2017). Place of residence as a measure of integration: changes in ethno-linguistic residential segregation. Estonian Human Development Report 2016-2017. Retrieved from https://inimareng.ee/ en/immigration-and-integration/place-of-residenceas-a-measure-of-integration

Leppik, M., \& Vihalemm, T. (2015). The paradox of national language acquisition: Russian-speakers' labour market positions in Estonia. Journal of Baltic Studies, 43(4), 471-496.

Lindeman, K. (2013). The school performance of the Russian-speaking minority in linguistically divided educational systems: A comparison of Estonia and Latvia. In Integration and inequality in educational institutions (pp. 45-69). Dordrecht: Springer.

Lindemann, K., \& Kogan, I. (2013). The role of language resources in labour market entry: Comparing Estonia and Ukraine. Journal of Ethnic and Migration Studies, 39(1), 105-123.

Loader, R., \& Hughes, J. (2017). Balancing cultural diversity and social cohesion in education: The potential of shared education in divided contexts. British Journal of Educational Studies, 65(1), 3-25.

Masso, A., \& Soll, M. (2014). Change in language of instruction in Russian medium schools: Multilevel analysis of attitudes and language proficiency. Journal of Baltic Studies, 45(4), 517-544.

McCarty, T. L. (2015). Ethnography in language planning and policy research. In F. M. Hult \& D. C. Johnson (Eds.), Research methods in language policy and planning: A practical guide (pp. 81-93). Hoboken: Wiley.

Peters, B. G. (2011). Institutional theory in political science: The new institutionalism. New York: Bloomsbury Publishing.

Pettigrew, T. F., \& Tropp, L. R. (2006). A meta-analytic test of intergroup contact theory. Journal of personality and social psychology, 90(5), 751.

Põder, K., Lauri, T., \& Rahnu, L. (2017). Challenges facing Estonian school system: The achievement gap between language stream schools and school choice by migrants 2017. Estonian Human Development Report 2016-2017. Retrieved from https://inimareng.ee/ en/immigration-and-integration/challenges-facingthe-estonian-school-system

Ryazanova-Clarke, L. (2014). Russian with an accent: Globalization and the post-Soviet imaginary. In L. Ryazanova-Clarke (Ed.), The Russian language outside the nation (pp. 249-280). Edinburgh: Edinburgh University Press.

Ricento, T. K., \& Hornberger, N. H. (1996). Unpeeling the onion: Language planning and policy and the ELT pro- 
fessional. Tesol Quarterly, 30(3), 401-427.

Schneider, T. (2015). Russian minority in Estonia: Social co-existence, educational transformation and the labor market. Bonn: Konrad Adenauer Foundation. Retrieved from http://www.kas.de/wf/en/33.40778

Schwartz-Shea, P., Yanow, D. (2013). Interpretive research design: Concepts and processes. Routledge.

Siiner, M. (2012). Towards a more flexible language policy: A comparative analysis of language policy design in Denmark and Estonia (PhD Dissertation). Tartu: Tartu University Press.

Siiner, M. (2014). Decentralisation and language policy: Local municipalities' role in language education policies. Insights from Denmark and Estonia. Journal of Multilingual and Multicultural Development, 35(6), 603-617.

Siiner, M., Koreinik, K., \& Brown, K. D. (2017). Language policy beyond the state. Dordrecht: Springer.

Siiner, M., \& L'nyavskiy-Ekelund, S. (2017). Priming language political issues as issues of state security: A corpus-assisted discourse analysis of language ideological debates in Estonian media before and after the Ukrainian crisis. In Language policy beyond the state (pp. 25-44). Dordrecht: Springer.

Smith, E. (2003). The constitution between politics and law. In The Constitution as an instrument of change (pp. 21-51).

Sonntag, S. K., \& Cardinal, L. (2015). Introduction. State traditions and language regimes: Conceptualizing language policy choices. In L. Cardinal \& S. K. Sonntag (Eds.), State traditions and language regimes (pp. 3-21). Montreal: McGill-Queen's University Press.

The Guide for the Development of Language Education Policies in Europe. (2017). Retrieved from https:// www.coe.int/t/dg4/linguistic/guide_niveau3_en.asp

Vihalemm, T., \& Hogan-Brun, G. (2013). Dilemmas of Estonian nation building in the open media market. Sociolinguistica, 27(1), 69-86.

Vihalemm, T., \& Siiner, M. (2013). Jätkusuutlik keelepoliitika: Kas ja kuidas? [Sustainable language policy: Why and how?]. Keel ja Kirjandus, 2013(2), 81-94.

Wlodarska-Frykowska, A. (2016). Ethnic Russian minority in Estonia. International Studies. Interdisciplinary Political and Cultural Journal, 18(2), 153-164.

\section{About the Authors}

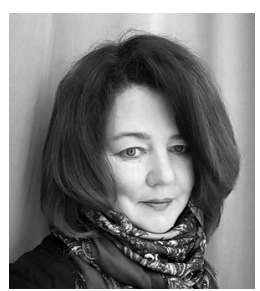

Svetlana L'nyavskiy-Ekelund is a PhD researcher at the Center for Central and Eastern European Studies at Lund University. She is investigating language policies, politics, planning and linguistic landscape from a sociolinguistic perspective, currently focusing on Russian speakers in Estonia and Ukraine. She is a co-author of a chapter in the edited volume Language Policy Beyond the State (with Siiner, Springer, 2017).

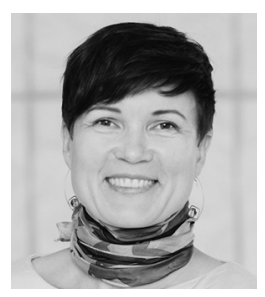

Maarja Siiner is PhD in language policy from the University of Tartu and is a Research Affiliate at the Center for Multilingualism in Society across the Lifespan, Center of Excellence, University of Oslo. She has analyzed language education policies from different theoretical and methodological angles, in both formal and informal settings, in Scandinavia and the Baltics. She is the co-editor of the edited volume Language Policy beyond the State (with K. Brown and K. Koreinik, Springer, 2017) and the edited volume Contemporary Perspectives on Language Acquisition Planning (with F. M. Hult and T. Kupisch, Springer, 2018). 